\title{
PENYULUHAN PENGOLAHAN MINUMAN KESEHATAN BERBAHAN DASAR KELOPAK BUNGA ROSELA SEBAGAI PENINGKAT IMUNITAS TUBUH DI MASA PANDEMI MELALUI APLIKASI ZOOM
}

\author{
Yani Ambari ${ }^{1}{ }^{*}$ Acivrida Mega Charisma ${ }^{2}$, Arista Wahyu Ningsih ${ }^{1}$, Elis Anita Farida ${ }^{2}$ \\ ${ }^{1}$ Program Studi S1 Farmasi, STIKES RS Anwar Medika, Sidoarjo, Indonesia \\ ${ }^{2}$ Program Studi DIII Teknologi Laboratorium Medik, STIKES RS Anwar Medika, Sidoarjo, Indonesia \\ *Email: yaniambari87@gmail.com
}

\begin{tabular}{|c|c|}
\hline Informasi Artikel & Abstrak \\
\hline $\begin{array}{l}\text { Kata kunci : } \\
\text { Antosianin, Minuman } \\
\text { Kesehatan, Bunga } \\
\text { Rosela, Tanaman } \\
\text { Herbal }\end{array}$ & $\begin{array}{l}\text { Awal Maret } 2020 \text { WHO (Organisasi Kesehatan Dunia) menetapkan wabah } \\
\text { virus corona sebagai pandemi global. Pencegahan terhadap penularan virus } \\
\text { corona ini adalah dengan meningkatkan sistem imun tubuh. Mengkonsumsi } \\
\text { tanaman herbal merupakan salah satu upaya untuk meningkatkan sistem } \\
\text { imun tubuh. Salah satu tanaman yang bermanfaat untuk meningkatkan } \\
\text { sistem imun tubuh adalah kelopak bunga rosela. Salah satu manfaat kelopak } \\
\text { bunga rosela adalah sebagai antioksidan, senayawa yang berperan sebagai } \\
\text { antioksidan adalah pigmen antosianin. Peran senyawa antioksidan dalam } \\
\text { kelopak bunga rosela adalah melindungi tubuh dari serangan radikal bebas } \\
\text { sehingga dapat membantu meningkatkan sistem imun tubuh. Pemanfaatan } \\
\text { kelopak bunga rosela adalah dengan mengolah menjadi minuman herbal. } \\
\text { Target pengabdian masyarakat adalah Keluarga Besar Istri Perum Bulog } \\
\text { (KBIB) cabang Surabaya Selatan. Kegiatan pengabdian masyarakat ini } \\
\text { dilakukan dengan } 4 \text { tahap, tahap pertama adalah persiapan, tahap yang } \\
\text { kedua adalah penyuluhan tentang manfaat kelopak bunga rosela serta cara } \\
\text { pengolahan menjadi minuman kesehatan melalui aplikasi zoom. Tahap } \\
\text { ketiga adalah pelatihan pembuatan minuman kesehatan kelopak bunga } \\
\text { rosela melalui video. Tahap keempat adalah penyerahan produk minuman } \\
\text { kesehatan berbahan dasar kelopak bunga rosela kepada Keluarga Besar Istri } \\
\text { Perum Bulog (KBIB) cabang Surabaya Selatan. Kegiatan pengabdian } \\
\text { masyarakat ini meningkatkan pengetahuan tentang manfaat kelopak bunga } \\
\text { rosela serta meningkatkan ketrampilan dalam mengolah tanaman herbal } \\
\text { menjadi minuman Kesehatan yaitu masyarakat dapat membuat sendiri } \\
\text { minuman kemasan dan minuman celup dengan bahan dasar Kelopak Bunga } \\
\text { Rosela. }\end{array}$ \\
\hline
\end{tabular}

Abstract

Keywords :

Anthocyanin, Health

Drink, Roselle Flower,

Herbal Plant Tanaman
In early March 2020, WHO, which is the World Health Organization, declared the disease caused by the corona virus a global pandemic. Prevention of the transmission of this corona virus is to increase the body's immune system. One way to increase the body's immune system is to consume herbal plants. Herbal plants that can be used to increase the body's immune system are rosella flower petals. Rosella flowers contain 
anthocyanin pigments which function as antioxidant compounds. Antioxidant compounds in roselle flower petals have a role in protecting the body from free radicals that can help increase body resistance. The use of roselle flower petals is to process them into herbal drinks. The target of community service is the extended family of the wife of Perum Bulog (KBIB) South Surabaya branch. The existence of training activities and processing of roselle petal health drinks can help boost the immune system during a pandemic. This community service activity is carried out in 4 stages, the first stage is preparation, the second stage is counseling about the benefits of roselle flower petals and how to process them into health drinks through the zoom application. The third stage is training on making rosella flower petal health drink through video. The fourth stage is the delivery of health drink products made from roselle petals to the extended family of the wife of Perum Bulog (KBIB) South Surabaya branch. This community service activity increases knowledge about the benefits of roselle petals and improves skills in processing herbal plants into health drinks.

\section{PENDAHULUAN}

Dunia pada awal tahun 2020 dikejutkan dengan adanya wabah penyakit yang dikenal dengan nama corona virus disease 19 atau Covid - 19. WHO sebagai organisasi kesehatan dunia menetapkan covid - 19 ini sebagai pandemi global pada awal maret 2020. Wabah Penyakit ini telah menyebar ke seluruh dunia dan jutaan orang di seluruh dunia sudah terjangkit penyakit ini. Penyakit covid - 19 akan semakin bertambah parah, apabila pasien memiliki riwayat penyakit kronis seperti diabetes, jantung, dan hipertensi. Gejala umum pada pasien yang terinfeksi Covid - 19 antara lain adalah gangguan pernapasan akut seperti demam, batuk dan sesak napas. Masa inkubasi rata-rata 5 - 6 hari dengan masa inkubasi terpanjang 14 hari. Pada kasus Covid - 19 yang berat dapat menyebabkan pneumonia, sindrom pernapasan akut, gagal ginjal, dan bahkan kematian. Tanda-tanda dan gejala klinis yang dilaporkan pada sebagian besar kasus adalah demam, dengan beberapa kasus mengalami kesulitan bernapas, dan hasil rontgen menunjukkan infiltrat pneumonia luas di kedua paru (Depkes, 2020). Salah satu bentuk upaya untuk mencegah terjadinya penyebaran Covid - 19 adalah meningkatkan sistem imun tubuh.

Upaya meningkatkan sistem imun tubuh salah satunya adalah dengan cara mengkonsumsi tanaman herbal. Salah satu tanaman herbal yang digunakan untuk meningkatkan sistem imun tubuh adalah bunga rosela (Hibicus Sabdariffa Linn). Tanaman rosela merupakan tanaman yang memiliki kelopak bewarna merah dan kelopak bunga rosela mengandung pigmen antosianin yang dapat berfungsi sebagai antioksidan dan bisa dijadikan sebagai suplemen untuk daya tahan tubuh. Semakin pekat warna merah pada kelopak bunga rosela, maka semakin banyak kandungan antosianin sebagai antioksidan semakin tinggi (Riendi, 2009).

Kandungan penting dari bunga rosela adalah pigmen antosianin yang membentuk flavonoid yang berperan sebagai antioksidan dan diyakini dapat menyembuhkan berbagai penyakit yaitu 
kangker, diabetes, hipertensi, gangguan liver, dan asam urat (Mardiah, 2009). Tiap 100gram kelopak kering bunga rosella mengandung $260-280 \mathrm{mg}$ vitamin $\mathrm{C}$, mengandung vitamin D dan B2. Kandungan vitamin C, 3 kali lipat dari anggur hitam, 9 kali lipat dari jeruk sitrus, 10 kali lipat dari buah belimbing dan 2,5 kali lipat dari jambu biji. Selain itu rosella kering mengandung kalsium tinggi (486/100g), magnesium serta omega 3, vitamin A, iron, potassium, $\beta$-karoten dan asam lemak esensial (winarti, 2010).

Dalam kegiatan pengabdian masyarakat yang kami lakukan, kami membuat minuman kesehatan peningkat sistem imun yang terbuat kelopak bunga rosela. Minuman kesehatan menurut Sethi (2004) merupakan suatu minuman yang dapat dikonsumsi untuk menghilangkan rasa haus dan dahaga, serta mempunyai manfaat kesehatan bagi tubuh. Efek kesehatan yang dimaksud adalah dapat mencegah dan mengobati berbagai penyakit serta untuk menjaga kesehatan tubuh jika dikonsumsi secara rutin. Minuman kesehatan memiliki beberapa produk seperti minuman fungsional, minuman probiotik, jus buah, minuman herbal, susu dan teh organik. Minuman kesehatan dapat didefinisikan sebagai produk minuman dalam kemasan yang memilki bentuk cair, serbuk, atau tablet yang memiliki kandungan gizi dan kesehatan terhadap tubuh (Assael, 1992)

Berdasarkan uraian di atas, kegiatan pengabdian masyarakat yang dilakukan oleh Tim Dosen STIKES Rumah Sakit Anwar Medika adalah tentang pengolahan minuman kesehatan berbahan dasar kelopak bunga rosela sebagai upaya pencegahan terhadap penyebaran wabah Covid - 19. Minuman kesehatan yang dibuat terdiri dari minuman rosela kemasan $250 \mathrm{~mL}$ dan minuman celup rosela. Berdasarkan hasil pengamatan yang telah dilakukan permasalahan mitra adalah masyarakat masih kurang tanggap dalam upaya pencegahan penyebaran wabah Covid - 19, khususnya dalam pentingnya menjaga sistem imun tubuh. Selain itu beberapa masyarakat belum memiliki cukup pengetahuan tentang cara mengolah tanaman herbal menjadi produk minuman kesehatan. Adanya kegiatan pengabdian masyarakat penyuluhan tentang manfaat dan pengolahan minuman kesehatan berbahan dasar kelopan bunga rosela ini dapat memberikan manfaat akan pentingnya menjaga sistem imun tubuh dengan mengkonsumsi minuman kesehatan sehingga dapat memutus mata rantai penyebaran wabah Covid - 19

\section{METODE}

Sasaran dari kegiatan pengabdian masyarakat ini adalah Keluarga Besar Istri Perum Bulog (KBIB) cabang Surabaya Selatan. Kegiatan Pengabdian Masyarakat ini dilakukan oleh Tim Dosen S1 Farmasi dan DIII Teknologi Laboratorium Medis STIKES RS Anwar Medika dengan dibantu oleh 4 Mahasiswa. Kegiatan pengabdian masyarakat ini dilakukan selama 4 minggu pada bulan Januari - 
Februari 2021. Pelaksanaan kegiatan pengabdian masyarakat ini dilakukan dengan beberapa tahap. Tahapan yang dilakukan meliputi:

a. Tahap pertama melakukan koordinasi dengan ketua Keluarga Besar Istri Perum Bulog (KBIB) cabang Surabaya Selatan. Diskusi ini dilakukan pada minggu terakhir bulan Januari 2021.

b. Tahap kedua melakukan persiapan untuk kegiatan pengabdian masyarakat. Persiapan yang dilakukan yaitu pembelian bahan - bahan (kelopak bunga rosela, gula, botol kemasan, kantung teh), desain kemasan, pembuatan video pengolahan minuman kesehatan, pembuatan materi dan brosur terkait manfaat kelopak bunga rosela dan cara pengolahan minuman kesehatan. Persiapan ini dilakukan di minggu pertama dan kedua bulan Februari 2021.

c. Tahap ketiga adalah memberikan penyuluhan tentang manfaat dan pengolahan tanaman herbal kelopak bunga rosela. Selain melakukan penyuluhan tim pengabdian masyarakat juga menampilkan video pembuatan minuman kesehatan berbahan dasar rosela. Penyuluhan dan pemutaran video dilakukan di minggu terakhir bukan februari yaitu pada tanggal 24 Februari 2021. Penyuluhan dan pemutaran video dilakukan dengan menggunakan media aplikasi zoom.

d. Tahap terakhir setelah penyuluhan adalah pembagian produk minuman kesehatan berbahan dasar rosela yang terdiri dari 50 botol minuman kemasan kelopak bunga rosela $250 \mathrm{~mL}$ dan 5 pack minuman celup kelopak bunga rosela.

\section{HASIL DAN PEMBAHASAN}

Kegiatan pengabdian masyarakat ini dilakukan melalui media aplikasi zoom. Penggunaan media zoom bertujuan untuk membatasi kunjungan ke tempat ramai dan kontak langsung dengan orang lain. Social distancing merupakan imbauan dari pemerintah yang bertujuan untuk mengurangi resiko penyebaran wabah Covid - 19. Kegiatan pengabdian masyarakat ini bertujuan untuk memberikan informasi tentang manfaat kelopak bunga rosela selain itu juga memberikan informasi tentang cara pengelolahan minuman kesehatan berbahan dasar kelopak bunga rosela.

Sebelum dilakukan pelatihan pengolahan minuman kesehatan berbahan dasar rosela melalui pemutaran video menggunakan aplikasi zoom, tim pengabdian masyarakat STIKES Rumah Sakit Anwar Medika melakukan penyuluhan. Penyuluhan terdiri dari 2 materi, materi pertama tentang manfaat tanaman herbal kelopak bunga rosela. Materi penyuluhan yang kedua tentang cara pengolahan minuman kesehatan berbahan dasar kelopak bunga rosela. Minuman herbal dapat dijadikan sebagai suatu produk olahan industri rumah tangga, minuman herbal merupakan minuman yang terbuat dari bagian-bagian tumbuhan dan memiliki manfaat untuk menjaga kesehatan tubuh serta dikonsumsi dengan cara diseduh dengan air mendidih (Tasia \& Widyaningsih, 2014). Setelah kegiatan penyuluhan selesai, kegiatan selanjutnya adalah pemutaran video tentang cara pengolahan minuman kesehatan berbahan dasar bunga rosela. 
Kegiatan yang terakhir adalah diskusi dan tanya jawab, walaupun kegiatan pengabdian masyarakat ini dilakukan menggunakan aplikasi zoom, peserta sangat antusias dalam melakukan diskusi. Beberapa pertanyaan diajukan oleh peserta terkait efek samping penggunaan minuman rosela jika digunakan setiap hari, juga pertanyaan terkait pengolahan rosela dalam bentuk lain selain bentuk minuman kesehatan. Peserta pengabdian masyarakat juga menyampaikan beberapa kesan selam mengikuti kegiatan, bahwa kegiatan ini membuat mereka ingin langsung mempraktekan secara langsung proses pengolahan kelopak bunga rosela menjadi minuman kesehatan.

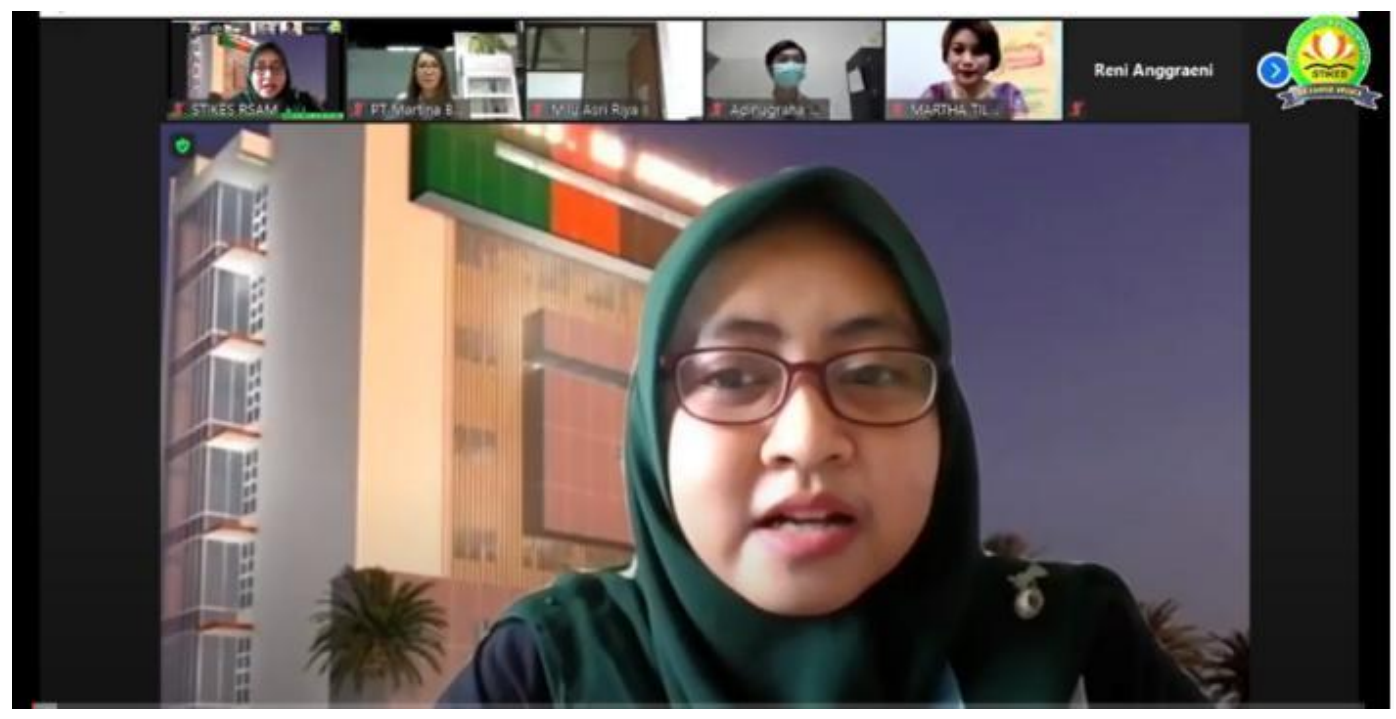

Gambar 1. Penyampaian Materi Penyuluhan Manfaat dan Pengolahan Minuman Kesehatan Berbahan Dasar Kelopak Bunga Rosela

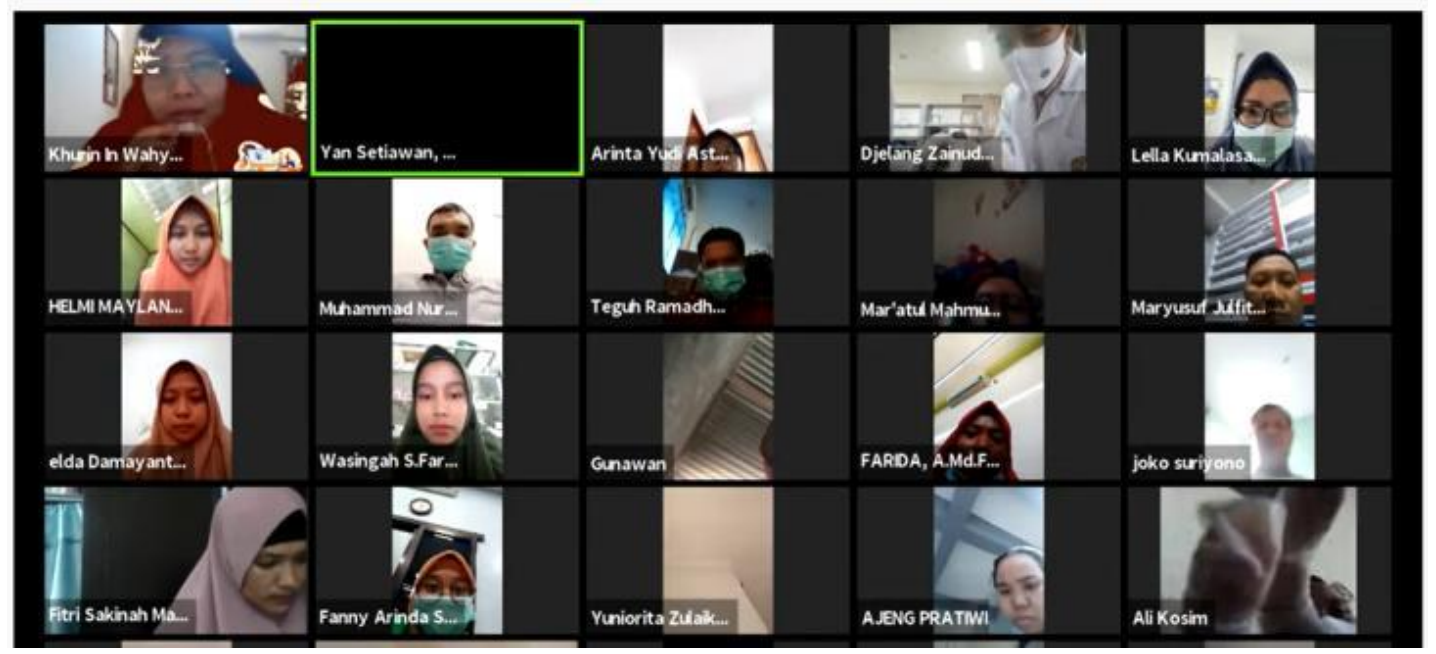

Gambar 2. Peserta Kegiatan Pengabdian Masyarakat 


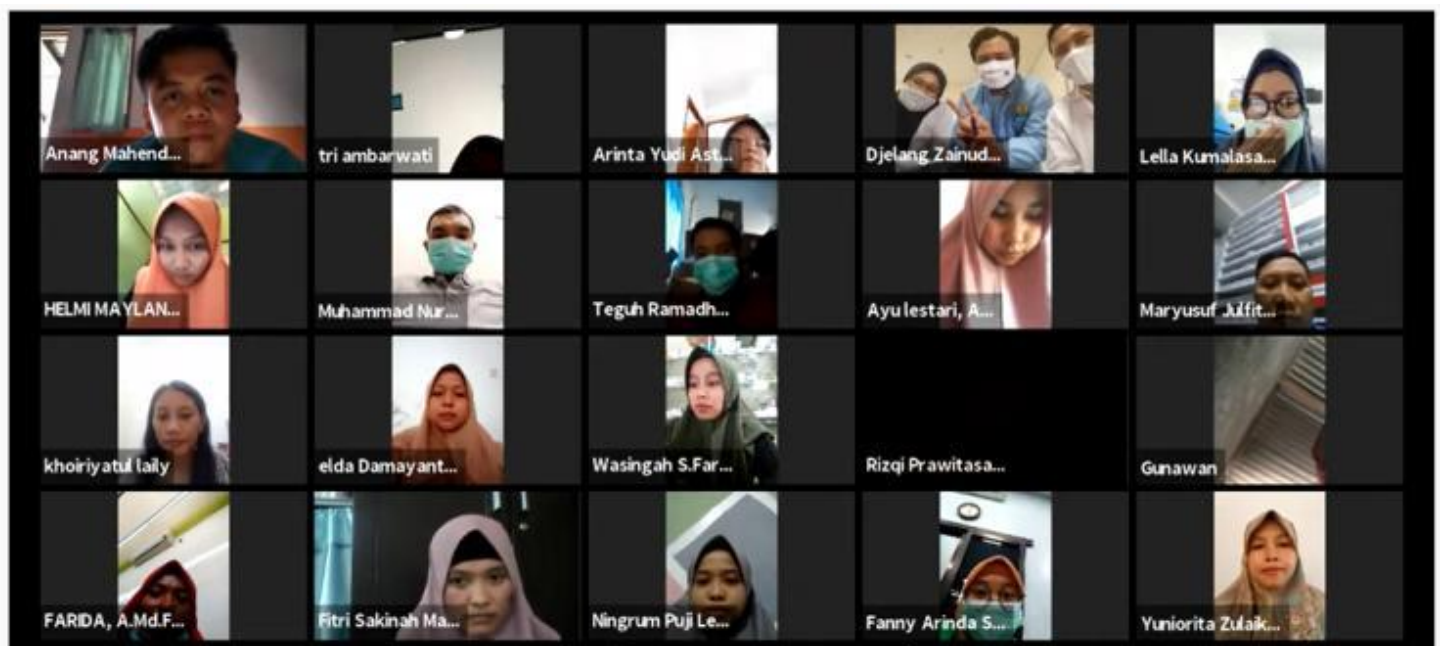

Gambar 3. Peserta Kegiatan Pengabdian Masyarakat

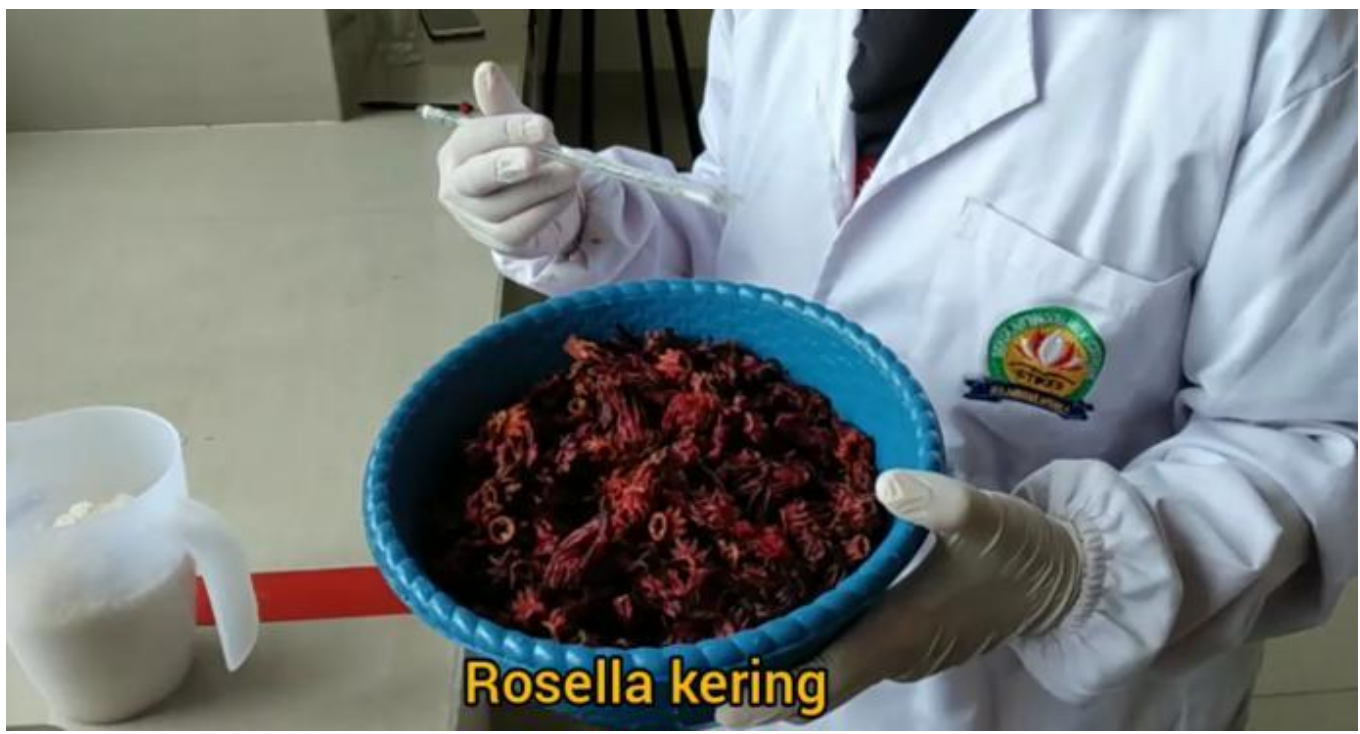

Gambar 4. Proses Pembuatan Minuman Kemasan Kelopak Bunga Rosela

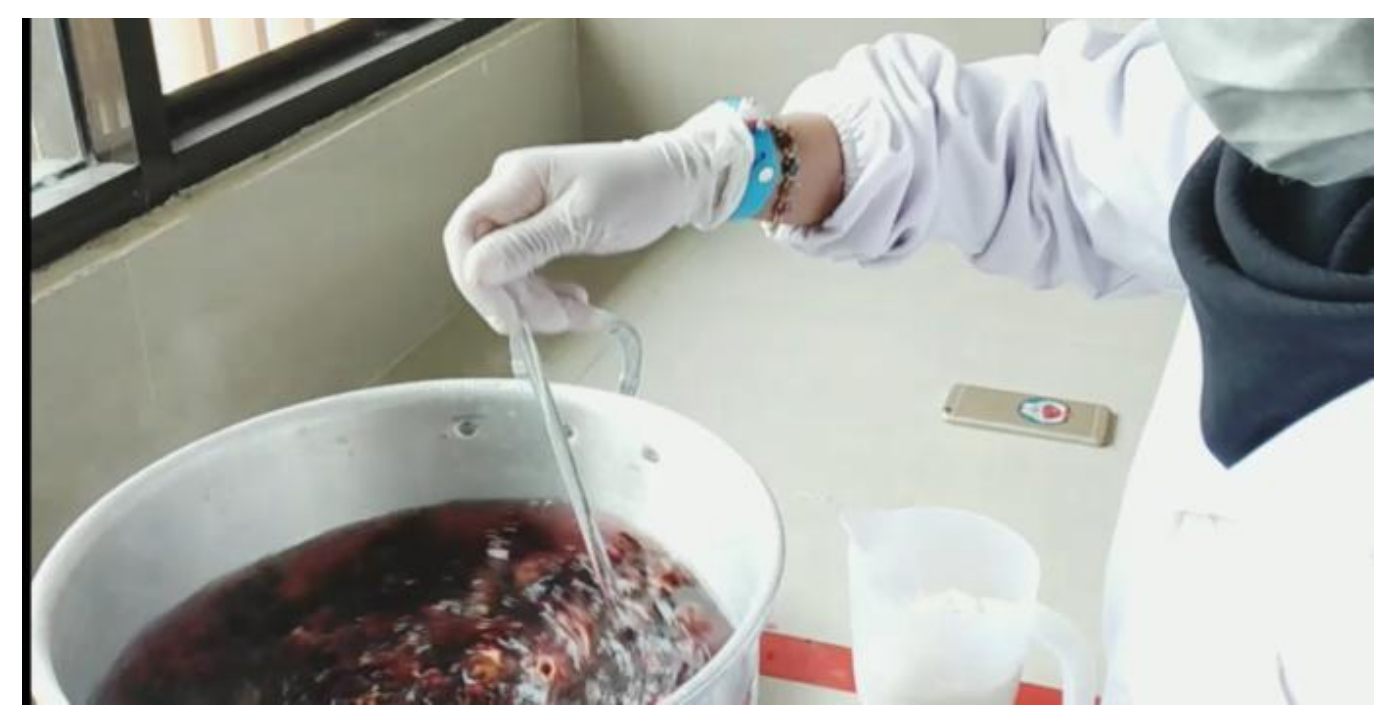

Gambar 5. Proses Pembuatan Minuman Kemasan Kelopak Bunga Rosela 


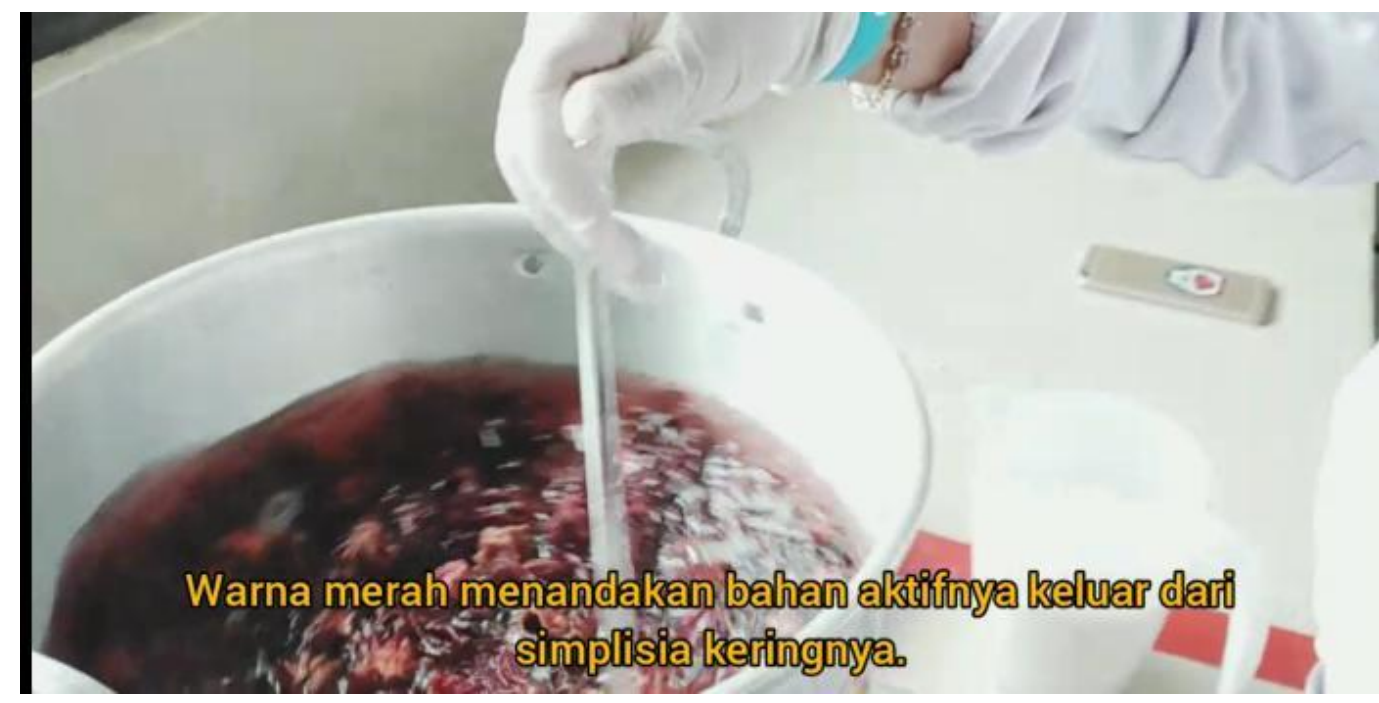

Gambar 6. Proses Pembuatan Minuman Kemasan Kelopak Bunga Rosela

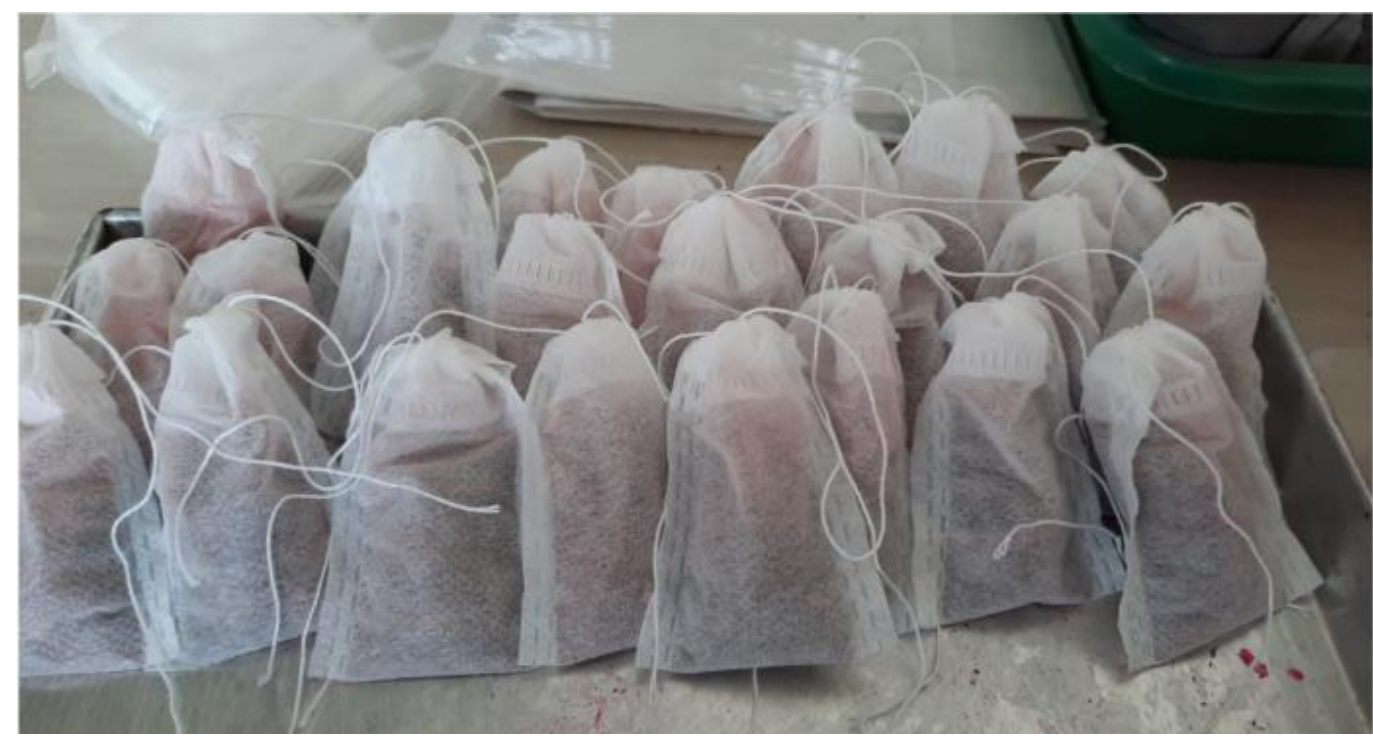

Gambar 7. Proses Pembuatan Minuman Celup Kelopak Bunga Rosela 


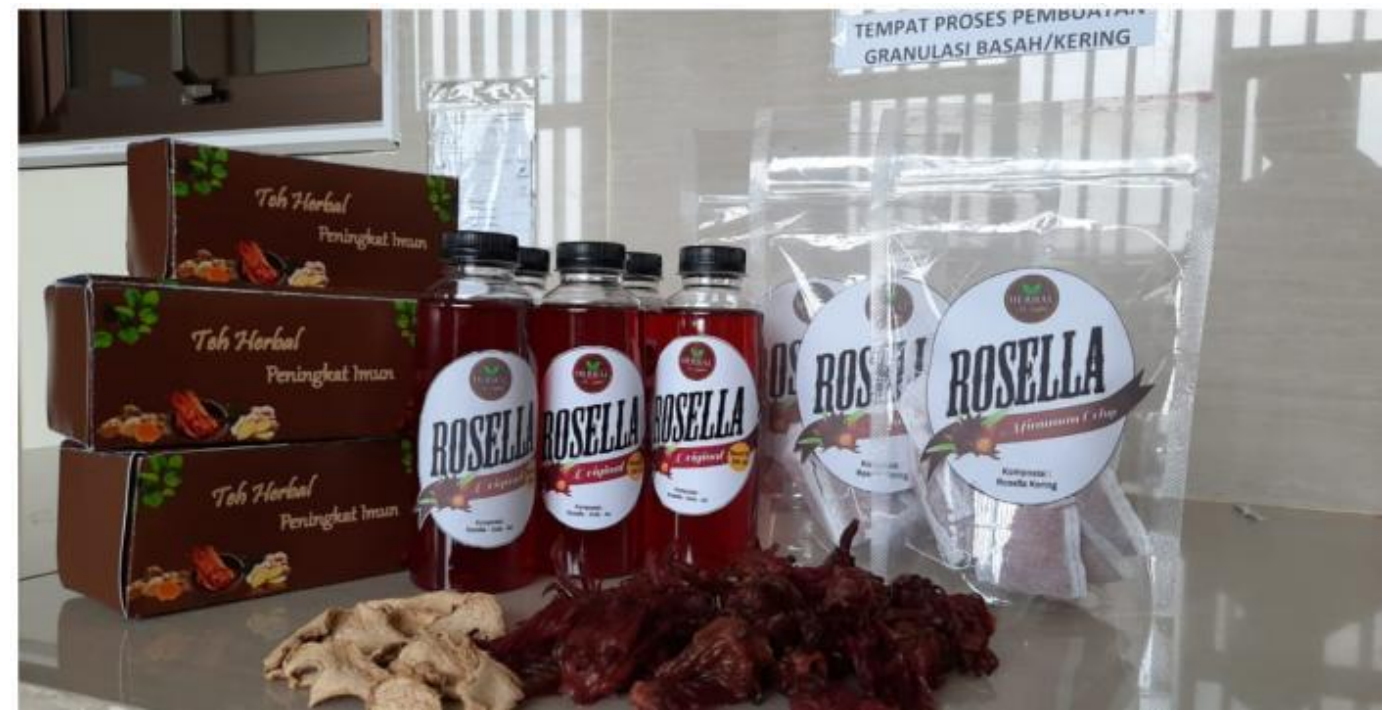

Gambar 8. Produk Minuman Kesehatan Berbahan Dasar Kelopak Bunga Rosela

Selain memberikan penyuluhan tentang cara pengolahan minuman kesehatan berbahan dasar kelopak bunga rosela, tim pengabdian masyarakat juga membagikan secara gratis 100 botol minuman kemasan ukuran $250 \mathrm{~mL}$ dan 5 pack minuman celup kelopak Bunga rosela untuk Keluarga Besar Istri Perum Bulog (KBIB) cabang Surabaya Selatan. Pembagian minuman kesehatan ini dilakukan secara langsung dengan berkunjung kantor BULOG cabang Surabaya Selatan, selain itu juga dibagikan di beberapa warga yang kebetulan sedang berada di jalan. Kegiatan ini mendapatkan respon positif dan warga sangat antusias saat pembagian minuman kesehatan berbahan dasar kelopak bunga rosela.

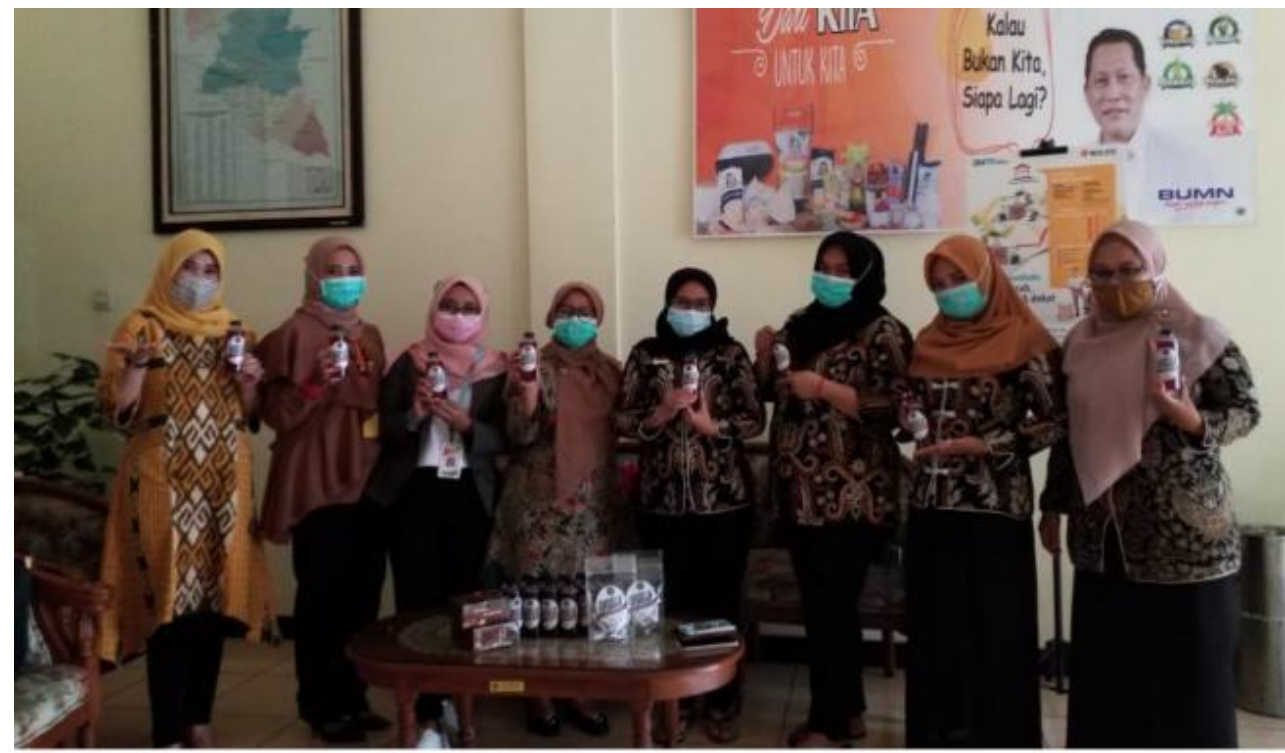

Gambar 7. Penyerahan Produk Minuman Kesehatan Berbahan Dasar Kelopak Bunga Rosela

Kegiatan pengabdian masyarakat ini, tidak hanya berakhir dengan penyuluhan, pelatihan dan penyerahan minuman kesehatan berbahan dasar rosela, tetapi tim pengabdian masyarakat STIKES RS 
Anwar Medika juga mendampingi masyarakat melalui grup whatshapp. Grup whatsapp ini menjadi sarana diskusi dengan masyarakat apabila masyarakat mengalami kesulitan dalam mengolah kelopak bunga rosela menjadi minuman kesehatan, selain itu masyarakat juga dapat berdiskusi mengenai manfaat manfaat tanaman herbal selain kelopak bunga rosela yang dapat meningkatkan sistem imun tubuh

\section{KESIMPULAN}

Kesimpulan dari pelaksanaan pengabdian masyarakat ini adalah meningkatnya pengetahuan masyarakat khususnya masyarakat Keluarga Besar Istri Perum Bulog (KBIB) cabang Suarabaya Selatan tentang manfaat kelopak bunga rosela sebagai peningkat sistem imun, selain itu masyarakat dapat mengolah kelopak bunga rosela menjadi minuman kesehatan seperti minuman kemasan ukuran $250 \mathrm{~mL}$ dan minuman celup kelopak bunga rosela.

\section{UCAPAN TERIMAKASIH}

Tim pengabdian masyarakat mengucapkan terima kasih kepada Keluarga Besar Istri Perum Bulog (KBIB) cabang Surabaya Selatan karena telah diberi kesempatan untuk melakukan kegiatan pengabdian masyarakat. Selain itu ucapan terima kasih juga ditujukan kepada Ketua STIKES dan ketua LPPM STIKES Rumah Sakit Anwar Medika yang telah memberikan ijin untuk melakukan kegiatan pengabdian masyarakat.

\section{DAFTAR PUSTAKA}

Assael, H. 1992. Consumer behavior and marketing action, 4th Edition. Massachusetts: PWS-Kent Publishing Company.

Depkes RI. 2020. Pedoman Pencegahan dan Pengendalian Corona Virus Desease (COVID19). Jakarta: Kemenkes RI \& Dirjen Pencegahan dan Pengendalian Penyakit.

Mardiyah. 2009. Budi Daya dan Pengolahan Rosella. Jakarta: Agromedia Pustaka.

Riendi. 2009. http://www.warungedukasi.co.cc/2009/02/rosella-sebagai-zat-antioksidan.html. (di unduh tgl 05 Februari 2021

Tasia, W. R., \& Widyaningsih, T. D. 2014. Potensi Cincau Hitam (Mesona palustris B1.) Daun Pandan (Pandanus amaryllifolius) Dan Kayu Manis (Cinnamomum burmannii) Sebagai Bahan Baku Minuman Herbal Fungsional. Jurnal Pangan dan Agroindustri. 2(4)

Winarti, Sri. 2010. Makanan Fungsional. Yogyakarta: Graha Ilmu 